\title{
Predicting Customers Use of Electronic Government Services in Nigeria
}

\author{
Kemi Ogunsola, University of Ibadan, Nigeria \\ iD https://orcid.org/0000-0002-3924-5879 \\ Mutawakilu Tiamiyu, University of Ibadan, Nigeria
}

\begin{abstract}
This study examined how customer use of electronic government services in Nigeria were being predicted by supply- and demand-side variables such as ICT deployment, customer readiness, perceived quality of e-government services, perceived satisfaction with e-government services, web readiness, and web presence quality. The results showed that for business organizations, only web presence quality of government websites, perceived satisfaction with the use of e-government services, and perceived quality of e-government services had predictive relationships with the use of e-government services. For the citizens, all the independent variables significantly predicted the use of e-government services, although ICT deployment predicted negatively citizens' use of e-government services. The study recommends among others that government agencies should deploy e-government services and channels that will improve the satisfaction to customers rather than providing only sophisticated services.
\end{abstract}

\section{KEYWORDS}

Customer Readiness, E-Government, E-Services, Government Agencies, ICT, Internet, Quality of E-Government Services, Satisfaction With E-Government Services, Web Presence Quality, Web Readiness

\section{INTRODUCTION}

Electronic government (e-government) services are those services which are delivered partly or wholly by the government to citizens and/or business organizations through the use of information and communication technologies (ICT) such as the Internet, mobile phones and others. Among such services are online application for a national passport, birth/marriage registration, registration of new business organizations, custom service declaration, bidding for government contracts, corporate tax declaration/notification, online application for scholarships, weather forecast and other services.

E-government services have brought improvement in terms of the roles and responsibilities of the government to both the citizens as well as business organizations (Ogunsola and Tiamiyu, 2017; Ronchi, 2019). This improvement could be in terms of increase in efficiency of governments' internal processes and quality of government interactions with citizens and business organizations (Curtin, Sommer and Vis-Sommer, 2003; Siew and Leng, 2003; Ogunsola and Ojebola, 2017; Ronchi, 2019). It has also helped in promoting government transparency and citizens' participation in government 
(Wong and Welch, 2004; Tiamiyu, 2005; Akunyili, 2010; Adebiyi, Ayo, and Adebiyi, 2010; DePaulaa, Dincellia and Harrison, 2018) with the use of services such as e-payment of employees' salaries, and allowances, and provision of government budgets on their websites. E-government enhances economic development which is capable of moving society towards the smart city and also in achieving the sustainability of the society (Faaeq, Mat, Faieq, Rasheed and Al-Salami, 2018).

Despite the various advantages of e-government, studies have shown that the level of use of e-government services in Nigeria is low (Tiamiyu and Ogunsola, 2008; Mohamed, Hussin and Hussein, 2009; Oni, Okunoye and Mbarika, 2016). Although, Nigeria laid the foundation for e-government in 2001 by providing the National IT policy for its implementation (Olatokun, 2006), yet Nigeria is still in the early stages of e-government adoption (Amagoh, 2016). Also, Nigeria's e-readiness is low (Adeyemo, 20011; United Nations, 2008, United Nations, 2010; Oni, Okunoye and Mbarika, 2016). Subsequent signs of progress have been seen when government agencies in Nigeria began to create websites. A survey conducted in 2013 showed that Nigeria has 210 websites at local, state and federal government levels (including the federal agencies and parastatals). These government websites were not integrated (Ogunsola, 2015; Ogunsola and Tiamiyu, 2017). As at the time of this study, many government agencies have adopted the use of social media such as Facebook, Twitter and others (Ogunsola and Ojebola, 2017; Ogunsola and Olojo, 2020). This is because; social media promotes government responsiveness to citizens by ensuring that the disconnection between the citizens and the governments are eliminated (Eom, Hwang and Kim, 2018).

Nigeria and many other developing countries have made investments in the provision of e-government services but unfortunately, many of such services are not been used by citizens (Mohamed, Hussin and Hussein, 2009). Even though government agencies report a high level of use of e-government services at times, many of their customers use the services indirectly through intermediaries and touts (Mohamed, Hussin and Hussein, 2009; Odili-Idiagbor, 2013). Even though e-government can improve government services delivery to citizens, the success of these government initiatives is dependent not only on government support but also on citizens' willingness to accept and adopt those e-government services (Rabaa ' $i$, 2015). There is, therefore, a need to find out reasons why citizens sometimes do not use e-government services at all or choose to patronize intermediaries and touts. This necessitated for this study, as it contributes to existing knowledge on factors predicting use of e-government services in Nigeria.

The use of e-government services in this study was assessed based on both demand-and supplyside variables, as an update on an aspect of a much larger study (Ogunsola, 2015), which investigated predictors of electronic government use in Nigeria. Demand-side variables in this study are important variables that explain the uptake of e-government services by customers, while supply-side variables are important variables in explaining the delivery of government services to the customers. Therefore, the interrelationships among six independent variables; consisting of three demand-side variables (customer readiness, perceived quality of e-government services, perceived satisfaction with e-government services) and three supply-side variables (ICT deployment, web readiness, and web presence quality) were investigated in this study.

This study's focus on these variables was informed by the following assumptions. Firstly, those e-government services are essentially ICT-driven; hence, the importance of levels of ICT deployment by relevant government agencies (supply-side variable). Secondly, the use of e-government services can only take place when such services are made available through appropriate electronic channels, particularly websites, by the relevant government agencies. Thus, the web readiness of government websites (supply-side variable) and the readiness of customers (demand-side variable) are major determinants in the use of e-government services. Furthermore, it is assumed that, if a user derives satisfaction while using a service, it is likely that the user will be ready to use the service another time, and the level of satisfaction derived will also be determined by the perceived quality of service. Hence, the focus on these two demand-side (perceived satisfaction and perceived quality of e-government 
services) variables as well. The assumed interrelationships among these variables provided the basis for the study's validated research model.

Customer e-readiness consists of e-readiness of citizens and business organizations to use government services. E-readiness of citizens is the measure of citizens' ability to use the computer, and/or mobile phone, and/or the Internet to access and use e-government services. E-readiness of business organization refers to the readiness of a business organization to access and use the provided e-government services, which depends on the availability of appropriate ICT and associated policy and human capital within the organization. Perceived quality of e-government services is defined in terms of measures of the relevance of service, reliability of service provided, ability to save time, the accuracy of the transaction, ease-of-use, usefulness of service, convenience, improved service delivery, faster services, and easy access to service delivered. Perceived satisfaction of government customers is the measure of the satisfaction users feel they derived in the course of using a particular e-government service via different ICT.

ICT deployment in a government agency is defined in terms of the availability of e-services provided online and mode of communication with the services, IT policy environment, information capital, human capital, and various ICT channels for the delivery of e-government services. Web readiness is defined as the preparedness of a government website to improve government services delivery, such as the provision of quality information and services on the website, such as e-mail address of government officials, e-mail address of the webmaster, and links to other government agencies, and regularly updated information valuable to citizens and business organizations to support their lives and operations respectively. Web presence quality is defined in terms of various quality attributes of a website, and is likely to increase the website's friendliness towards its users, such an in navigation and orientation, text equivalents, scripting, styling, HTML standards, and availability of web 2.0. features.

To derive the interrelationships among the independent and the dependent variables, the following objectives were set for the study:

1. to assess the importance of ICT deployment, customer readiness, perceived quality, perceived satisfaction, web readiness, and web presence quality in predicting the use of e-government services in Nigeria.

2. to validate a framework for promoting ICT deployment for improved effectiveness and use of e-government services at all levels of government in Nigeria.

The research hypotheses of this study are presented for citizens and business organizations, respectively, as follow:

$\mathrm{H}_{01}$ : There is no significant predictive joint influence of the independent variables (ICT deployment of government services, web readiness of e-government websites, web presence quality of government websites, customer readiness, perceived quality of e-government services, and perceived satisfaction with e-government services) on use of e-government services by citizens.

$\mathrm{H}_{02}$ : There is no significant predictive joint influence of the independent variables (ICT deployment of government services, web readiness of e-government websites, web presence quality of government websites, customer readiness, perceived quality of e-government services, and perceived satisfaction with e-government services) on use of e-government services by business organizations.

\section{LITERATURE REVIEW}

The study investigated the predictive interrelationships among seven supply- and demand-side variables considered relevant to understanding the dynamics of e-government delivery and uptake in Nigeria: ICT deployment (by government agencies), web readiness (of government websites), web presence quality (of government websites), customer readiness (of citizens and business organization to access 
and use e-government services), perceived quality (of e-government websites by customers), perceived satisfaction (with e-government services reported by customers), and the use of e-government services (by citizens and business organizations) in Nigeria.

An earlier study (Colesca and Liliana, 2008) used the extended version of the Technology Acceptance Model (TAM) to investigate the relationship between uses of e-government services, quality of service and user satisfaction, found out that there is a significant relationship between the use of e-government services, satisfaction with service and service quality in Romania. The study by Kalamatianou (2017) focused on developing technology adoption model based on the Unified Theory of Acceptance and the Use of Technology (UTAUT2) model, enhancing it with four additional criteria. The findings reveal that behavioral intention and usage intention are influenced by enablers, such as effort expectancy, performance expectancy, social influence, price value and habit, as well as inhibitors such as privacy, profession and user satisfaction with e-services in Greece.

The study by Ogunsola and Ojebola (2017) found that the quality of information disseminated by agencies through Facebook had a significant relationship with the frequency of use of e-government services in Nigeria. The study by Mohamed, Hussin and Hussein (2009) examined user satisfaction and factors influencing it, such as content, accuracy, timeliness, format and ease-of-use in Malaysia's electronic government services. The study used the End-User Computing Satisfaction (EUCS) model to measure internal users' satisfaction. The result showed that ease-of-use, as well as content, accuracy, timeliness, and format, contribute to user satisfaction.

The study by Alomari, Woods and Sandhu (2009) adopted the Diffusion of Innovation Theory (DOI) and the Technology Acceptance Model (TAM), in examining social factors influencing e-government adoption and use in Jordan. Social factors such as trust, attitude and belief, education and accessibility were discovered to predict the use of e-government. Furthermore, the study by AlGhaith, Sanzogni and Sandhu (2010), based on the Diffusion of Innovation (DOI) theory, investigated those variables that influence the adoption and use of e-services in Saudi Arabia. The result showed a significant positive relationship between quality of service (measured by perceived complexity, privacy and compatibility and, quality of e-service) and use of e-services. Keramati, Behmanesh and Noori (2018) presented a conceptual model to determine the role of readiness factors in the relationship between e-government factors and e-government outcomes. The results show readiness factor plays a moderating role in the relationship between e-government factors and e-government outcomes, and that organizational readiness factors have the most important effect on e-government outcomes in Iran.

Oni, Okunoye and Mbarika (2016) conducted content analysis of the official websites of the thirtysix states and the federal capital territory in Nigeria. It showed that only twenty-three (64 per cent) had websites and mostly provide textual information; few provide downloadable digital documents and functional online interactions. Quirchmayr, Funilkul and Chutimaskul (2007) addressed the quality model of e-Government services (e-GSQ Model) by employing the ISO/IEC 9126 standard. This model is used to verify government services whether or not they meet citizens' needs. The result of tested quality metrics for e-government services supports the basic characteristics of a quality model of e-government services. The study by Dibie and Quadri (2018) examines the extent to which e-government has facilitated a better relationship between citizens and the federal government of Nigeria. The findings show that there is a negative correlation between the e-governance initiatives and federal government efficient service delivery in Nigeria, also there is a negative correlation between citizens and federal government relations in the country.

Most of the studies highlighted above were based either on the user behavioural (demand-side) variables or the e-service provision and technology (supply-side) variables. There is, therefore, a major knowledge gap on the interrelationships between the supply and demand-side variables of e-government services. Since understanding the interrelationships involve considering the dynamic interplay of technological and behavioural variables, the socio-technical interaction networks theory (STIN) was considered as the most appropriate existing theoretical framework for guiding the study. The socio-technical interaction networks theory (STIN) is based upon the assumption that ICT are not 
just tools or objects which can be analyzed separately from their users, but that they are intertwined with social relations and resources (Kling, 2000). This theory informed both the research model for the study (see Figure 3) and the data collection methodology adopted for the study which involved the survey of citizens, business organizations, public servants as well as analysis of government websites.

\section{EMPIRICAL RESEARCH}

\section{Research Design}

The study adopted a descriptive research design. The design involved the use of methodology triangulation, implemented through two main data collection methods; questionnaire administration for government officials, and customers (citizens and business organizations), and the content analyses of the government websites.

\section{Study Populations and Samples}

Data collection were carried out among officials of purposively selected government agencies, citizens and business organizations in three major cities of Nigeria - Lagos (the largest city by population with the largest seaport), Port Harcourt (the second largest port city and the state capital of one of the richest oil-producing states) and Abuja (national capital city, which also hosts the headquarters of most federal government ministries and agencies). The environments of the selected cities, including their large and growing populations, attract large numbers of commercial, financial, educational activities as well as government services and others thus creating large possibilities for the delivery and use of e-government services.

The sample size was selected according to each type of population in this study, that is: (a) citizens, (b) business organizations, (b) public servants, and (c) government websites. According to Gay and Airasian (2000), if the population is around 1500, a sample of $20 \%$ should be selected. For the populations represented in the study, either the total population was surveyed or $40 \%$ of the population was selected. For this study, citizens were contacted at various services points.

A preliminary study conducted by the researchers revealed that the estimated average total population of citizens at the services points for two weeks is two thousand, eight hundred $(2,800)$, from which $40 \%$ that is, 1,120 respondents were selected. As the survey of public servants was to get representatives from each agency who can give information on the organizations level of ICT deployment, two senior management-level cadre officers were purposively selected per agency; thus, for 30 purposively selected government agencies, 60 management cadre officers were sampled, this was in addition to 120 IT officers who were sampled from the 390 IT officers employed within the government agencies. A total of 180 public servants were sampled. All the two hundred and ten (210) websites of ministries, departments and agencies (MDAs) available at the time of the study were surveyed for data collection and assessment (see Appendices1 and 2).

The total population of business organizations (micro, small and medium) could not be ascertained. The major reason for this is the lack of any official figures of the population of formal or informal business organizations from the National Bureau of Statistics, as well as the Corporate Affairs Commission, Nigeria. This is because many micro and small businesses are not registered. Thus, the sampling strategy for business organizations was to sample 360 respondents from them, stratified by city and size, purposively and conveniently.

Kaylor, Deshazo and Van Eck (2001), in their content analysis of websites of US municipalities, provide a means of benchmarking e-government implementation, which assigns e-scores to cities based on the functions and services that the websites provided. This approach was adopted for the content analysis of government agencies in Nigeria. Moreover, to do a content analysis of government websites, benchmarking of Nigeria government services was carried out. This involved the selection of samples of websites from developed and developing countries. The study by Accenture (2005) 
ranked twenty-one countries for five years about their e-government maturity growth. The first, eleventh and twenty-first ranked countries were selected from the Accenture list as the benchmark countries, which were Canada, Republic of Ireland and South Africa.

For the benchmark countries, the Canadian national portal and three websites of the three selected provinces (Ontario, Saskatchewan and Nova Scotia) out of the available ten were assessed. The Republic of Ireland had a national government website, did not have provincial (state) government websites; but had 16 websites for government agencies (departments), out of which six were selected in addition to the national portal. The following six agencies which had similar services to those identified in Nigeria were purposively sampled, namely: Revenue, Pensions Board, e-Procurement, Department of Education and Skills, Department of Foreign Affairs and Trade, Aviation-Air Space Management. For South Africa, there are 9 provinces, and the South African national portal and the websites of three provinces (Western Cape, Gauteng and Eastern Cape) were selected.

In summary, the purposive sampling method was used in the selection of government websites in Nigeria, while the stratified random sampling method was used in the selection of websites of the benchmark countries. Convenience sampling was used for the selection of public servants and citizens, while the snowballing technique was used for selecting business organizations.

\section{Test of Instruments}

For the study, pilot tests were conducted. Separate questionnaires for citizens, business organizations and public servants were designed and validated using test-retest correlation methods. The test-retest correlation of the questionnaires for citizens, business organizations and public servants were 0.91 , 0.87 , and 0.79 , respectively. Also, a checklist was designed by the researchers based on criteria identified through the literature review and the benchmarking exercise. They were thereafter tested by using it to assess 30 government websites in Nigeria, to see if the checklist adequately captured the variety of features of government websites.

\section{Data Collection}

Data collection with the questionnaires was carried out in the three selected cities for three months. Content analysis and assessment of the websites of the benchmarking countries was done by the researchers themselves because the results were used to design the checklist that was used for the assessment of the Nigerian government websites. It was after the design of the checklist that the designed instrument was used for the assessment of Nigerian government websites. The researchers and their two assistants used three months to search for, access and assess the selected Nigerian government websites, using the checklist. But, any of the identified government websites that could not be accessed within the survey period was removed from the list of websites assessed. Also, the Functional Accessibility Evaluator (FAE) software version 1.1was used to generate reports, which were used as part of the results for calculating the web presence quality. FAE is an open-source software developed by the University of Illinois at Urbana-Champaign, United States of America.

\section{Demographics of Respondents}

Data were collected in respect of the perceptions and assessments of citizens and business organizations (as current or potential users of e-government services) and public servants (as operators of such services), and knowledgeable and skilled information science and technology people (as assessors of the web readiness and web presence quality of e-government websites). This section provides the frequency analyses of the demographic and other attributes of the samples.

\section{Citizens}

The total number of citizens who responded to the survey was 888 out of a target of 1120 respondents; therefore, the response rate was $79.3 \%$. Out of a total of 888 respondents, 520 (58.55\%) were males, while 367 (41.31\%) were females. Distributions according to the study location were as follows: 365 
(41.10\%) respondents were from Abuja; 253 (28.49\%) respondents from Lagos; and 270 (30.30\%) respondents from Port Harcourt. The distribution of citizen respondents showed that respondents within the age range of 26-35 years had the highest frequency count of $270(30.41 \%)$; this was followed by those in the age group 16-25 years, with 213 (23.99\%) respondents. The age group 36-45 years had $206(23.20 \%)$ respondents; while respondents aged 56 years and above had the least frequency count of $51(5.74 \%)$ respondents, as presented in Table 1.

Table 1. Distribution of citizen respondents by location and age $(\mathrm{N}=888)$

\begin{tabular}{|l|l|l|l|l|l|l|}
\hline \multicolumn{1}{|c|}{ Location } & \multicolumn{1}{|c|}{$\mathbf{1 6 - 2 5}$ years } & \multicolumn{1}{|c|}{$\mathbf{2 6 - 3 5}$ years } & \multicolumn{1}{|c|}{$\mathbf{3 6 - 4 5}$ years } & \multicolumn{1}{|c|}{ 46-55 years } & \multicolumn{1}{|c|}{$\mathbf{6 6 +}$ years } & Total \\
\hline Abuja & $117(13.18 \%)$ & $90(10.14 \%)$ & $78(8.78 \%)$ & $60(6.76 \%)$ & $20(2.25 \%)$ & $365(41.10 \%)$ \\
\hline Lagos & $37(4.17 \%)$ & $67(7.55 \%)$ & $66(7.43 \%)$ & $56(6.31 \%)$ & $27(3.04 \%)$ & $253(28.49 \%)$ \\
\hline $\begin{array}{l}\text { Port } \\
\text { Harcourt }\end{array}$ & $59(6.64 \%)$ & $113(12.73 \%)$ & $62(6.98 \%)$ & $32(3.60 \%)$ & $4(0.45 \%)$ & $270(30.41 \%)$ \\
\hline Total & $213(23.99 \%)$ & $270(30.41 \%)$ & $206(23.20 \%)$ & $148(16.67 \%)$ & $51(5.74 \%)$ & $\mathbf{8 8 8}$ \\
\hline
\end{tabular}

\section{Public Servants}

Out of an estimated 180 respondents who were public servants, 117 responded; therefore, the response rate was $65 \%$. In this study, female public servants were more responsive than their male counterparts. A total of $72(61.54 \%)$ were females; while $45(38.46 \%)$ respondents were males (see Table 2).

Table 2. Distribution of public servants respondents by location and sex $(\mathrm{N}=117)$

\begin{tabular}{|l|l|l|l|}
\hline \multicolumn{1}{|c|}{ Location } & \multicolumn{1}{c|}{ Male } & \multicolumn{1}{c|}{ Female } & \multicolumn{1}{c|}{ Total } \\
\hline Abuja & $18(15.38 \%)$ & $38(32.48 \%)$ & $56(47.86 \%)$ \\
\hline Lagos & $19(16.24 \%)$ & $21(17.95 \%)$ & $40(34.19 \%)$ \\
\hline Port Harcourt & $8(6.84 \%)$ & $13(11.11 \%)$ & $21(17.95 \%)$ \\
\hline Total & $45(38.46 \%)$ & $72(61.54 \%)$ & $\mathbf{1 1 7}$ \\
\hline
\end{tabular}

As captured in Table 3, the distribution of public servants according to their departments showed that the highest number of respondents were from the administration department who had spent 6-10 years in public service, that is 28 (24.35\%); while the same number were from the information technology and related departments who had spent 1-5 years in the public service. Two respondents out of 117 respondents did not indicate their years of experience. The data showed that the respondents in the administration department had more years of experience than those from the IT and related departments (see Table 3).

\section{Business Organizations}

For business organizations, 156 (50.16\%) copies of the questionnaire were retrieved from Abuja, 117 (37.62\%) from Lagos, and 38 (12.22\%) from Port Harcourt. Responses were obtained from these categories of business sectors: agriculture, finance/insurance, ICT equipment and services, manufacturing, hospitality, education, sales of electronics and other goods, building and architecture, travel agencies, entertainment industries, property business, postal services, supermarket, importation 
Table 3. Distribution of public servants by department and years of experience in public service $(\mathrm{N}=117)$

\begin{tabular}{|c|c|c|c|c|c|c|}
\hline \multirow[b]{2}{*}{ Department } & \multicolumn{5}{|c|}{ Years of experience in public service } & \multirow[b]{2}{*}{ Total } \\
\hline & 1-5 Years & 6-10 Years & 11-15 Years & 16-20 Years & 21-25 Years & \\
\hline Missing value & - & - & - & - & - & 2 \\
\hline IT/related department & $\begin{array}{l}28 \\
(24.35 \%)\end{array}$ & $\begin{array}{l}17 \\
(14.78 \%)\end{array}$ & $\begin{array}{l}9 \\
(7.82 \%)\end{array}$ & $\begin{array}{l}4 \\
(3.47 \%)\end{array}$ & $\begin{array}{l}2 \\
(1.74 \%)\end{array}$ & $\begin{array}{l}60 \\
(52.17 \%)\end{array}$ \\
\hline $\begin{array}{l}\text { Administration } \\
\text { department }\end{array}$ & $\begin{array}{l}11 \\
(9.56 \%)\end{array}$ & $\begin{array}{l}28 \\
(24.35 \%)\end{array}$ & $\begin{array}{l}10 \\
(8.70 \%)\end{array}$ & $\begin{array}{l}4 \\
(3.47 \%)\end{array}$ & $\begin{array}{l}2 \\
(1.74 \%)\end{array}$ & $\begin{array}{l}55 \\
(47.83 \%)\end{array}$ \\
\hline Total & $\begin{array}{l}39 \\
(33.91 \%)\end{array}$ & $\begin{array}{l}45 \\
(39.13 \%)\end{array}$ & $\begin{array}{l}19 \\
(16.52 \%)\end{array}$ & $\begin{array}{l}8 \\
(6.94 \%)\end{array}$ & $\begin{array}{l}4 \\
(3.48 \%)\end{array}$ & 117 \\
\hline
\end{tabular}

and clearing of goods, sale of petroleum products, hairdressing and beauty services, telecommunication, consulting firms.

The category of respondents from business organizations established between 2001 and 2005 $(110,35.37 \%)$ was most represented, closely followed by respondents from organizations established in 2006-2010 $(105,33.76 \%)$. The least represented respondents were from organizations established in 2011 or later (see Table 4).

\section{Descriptive Statistics of Variables}

Descriptive statistics were presented for the seven variables from the citizens' data (Table 5). These statistics showed that, comparatively, the variability of five variables were moderate as the standard deviation were below half of the mean, while the standard deviation of two of the variables (Satisfaction with Use of E-government Websites, and Use of E-government services) was a little above half of the mean. Normality test was done and using histograms with curve showed that only Citizens readiness was a little skewed.

For business organization data, descriptive statistics were also presented for the seven variables (Table 6). These statistics showed that variability of three variables was moderate as the standard deviation were below half of the mean, while the standard deviation of the other four variables (ICT Deployment, Web Readiness of E-government Websites, and Web Presence Quality of Government Websites and Business Organizations Readiness) were a little above half of the mean. Normality test was done and using histograms with curve showed that only Business organizations readiness was a little skewed.

Table 4. Distribution of business organizations by location and years of establishment $(\mathrm{N}=311)$

\begin{tabular}{|c|c|c|c|c|c|}
\hline \multirow[b]{2}{*}{ Location } & \multicolumn{4}{|c|}{ Years of establishment } & \multirow[b]{2}{*}{ Total } \\
\hline & 2000 and Below & 2001-2005 & 2006-2010 & $\begin{array}{l}2011 \text { and } \\
\text { Above }\end{array}$ & \\
\hline Abuja & $\begin{array}{l}26 \\
(8.36 \%)\end{array}$ & $\begin{array}{l}70 \\
(22.50 \%)\end{array}$ & $\begin{array}{l}53 \\
(17.04 \%)\end{array}$ & $\begin{array}{l}7 \\
(2.25 \%)\end{array}$ & $\begin{array}{l}156 \\
(50.16 \%)\end{array}$ \\
\hline Lagos & $\begin{array}{l}27 \\
(8.68 \%)\end{array}$ & $\begin{array}{l}34 \\
10.93 \%)\end{array}$ & $\begin{array}{l}45 \\
(14.47 \%)\end{array}$ & $\begin{array}{l}11 \\
(3.54 \%)\end{array}$ & $\begin{array}{l}117 \\
(37.62 \%)\end{array}$ \\
\hline Port Harcourt & $\begin{array}{l}15 \\
(4.82 \%) \\
\end{array}$ & $\begin{array}{l}6 \\
(1.93 \%) \\
\end{array}$ & $\begin{array}{l}7 \\
(2.25 \%) \\
\end{array}$ & $\begin{array}{l}10 \\
(3.22 \%)\end{array}$ & $\begin{array}{l}38 \\
(12.22 \%) \\
\end{array}$ \\
\hline Total & $\begin{array}{l}68 \\
(21.86 \%)\end{array}$ & $\begin{array}{l}110 \\
(35.37 \%)\end{array}$ & $\begin{array}{l}105 \\
(33.76 \%)\end{array}$ & $\begin{array}{l}28 \\
(9.01 \%)\end{array}$ & 311 \\
\hline
\end{tabular}


Table 5. Descriptive Statistics for Variables from Citizens Data $(\mathrm{N}=888)$

\begin{tabular}{|c|c|c|c|c|c|c|c|c|}
\hline & & $\begin{array}{c}\text { ICT } \\
\text { Deployment }\end{array}$ & $\begin{array}{c}\text { Web } \\
\text { Readiness of } \\
\text { E-government } \\
\text { Websites }\end{array}$ & $\begin{array}{l}\text { Web Presence } \\
\text { Quality of } \\
\text { Government } \\
\text { Websites }\end{array}$ & $\begin{array}{c}\text { Satisfaction } \\
\text { with Use of } \\
\text { E-government } \\
\text { Websites }\end{array}$ & $\begin{array}{c}\text { Quality of } \\
\text { E-government } \\
\text { Services as perceived } \\
\text { by Citizens }\end{array}$ & $\begin{array}{l}\text { Citizens' } \\
\text { Readiness }\end{array}$ & $\begin{array}{c}\text { Use of } \\
\text { e-government } \\
\text { services }\end{array}$ \\
\hline \multirow[t]{2}{*}{$\mathbf{N}$} & Valid & 849 & 888 & 888 & 888 & 888 & 888 & 888 \\
\hline & Missing & 39 & 0 & 0 & 0 & 0 & 0 & 0 \\
\hline \multicolumn{2}{|c|}{ Mean } & 29.2484 & 12.9914 & 82.6162 & 19.0101 & 51.8863 & 7.3840 & 5.2286 \\
\hline \multicolumn{2}{|c|}{ Median } & 30.7500 & 13.0000 & 88.8500 & 20.0000 & 58.0000 & 9.0000 & 4.0000 \\
\hline \multicolumn{2}{|c|}{ Std. Deviation } & 12.29856 & 6.84090 & 24.07554 & 12.60308 & 24.06023 & 2.64384 & 3.91145 \\
\hline
\end{tabular}

Table 6. Descriptive Statistics for Variables from Business Organizations Data ( $\mathrm{N}=311$ )

\begin{tabular}{|c|c|c|c|c|c|c|c|c|}
\hline & & $\begin{array}{l}\text { ICT } \\
\text { Deployment }\end{array}$ & $\begin{array}{l}\text { Web } \\
\text { Readiness of } \\
\text { E-government } \\
\text { Websites }\end{array}$ & $\begin{array}{l}\text { Web Presence } \\
\text { Quality of } \\
\text { Government } \\
\text { Websites }\end{array}$ & $\begin{array}{l}\text { Satisfaction } \\
\text { with Use of } \\
\text { E-government } \\
\text { Websites }\end{array}$ & $\begin{array}{l}\text { Quality of } \\
\text { E-government } \\
\text { Services as } \\
\text { perceived } \\
\text { by Business } \\
\text { Organizations }\end{array}$ & $\begin{array}{l}\text { Business } \\
\text { Organizations } \\
\text { Readiness }\end{array}$ & $\begin{array}{l}\text { Use of } \\
\text { e-government } \\
\text { services }\end{array}$ \\
\hline \multirow[t]{2}{*}{$\mathbf{N}$} & Valid & 286 & 309 & 309 & 311 & 311 & 311 & 311 \\
\hline & Missing & 25 & 2 & 2 & 0 & 0 & 0 & 0 \\
\hline \multicolumn{2}{|c|}{ Mean } & 27.9280 & 13.2751 & 69.9735 & 31.2058 & 54.4148 & 30.9775 & 9.0868 \\
\hline \multicolumn{2}{|c|}{ Median } & 30.7500 & 13.2500 & 90.7300 & 33.0000 & 60.0000 & 27.0000 & 8.0000 \\
\hline \multicolumn{2}{|c|}{ Std. Deviation } & 17.11870 & 8.35335 & 37.50303 & 15.20429 & 24.35500 & 20.15367 & 4.31376 \\
\hline
\end{tabular}

\section{RESULTS}

\section{Research Hypothesis One (Citizens' Use of E-Government Services)}

There is no significant predictive joint effect of the independent variables (ICT deployment of government services, customer readiness, perceived quality of e-government services, perceived satisfaction with e-government services, web readiness of e-government websites and web presence quality) on use of e-government services by citizens.

To answer this research hypothesis for citizens, multiple regression analysis was performed (Table 7). Table 7 shows that the joint effect of the independent variables (ICT deployment of government services, readiness to use e-government services, perceived quality of e-government services, and perceived satisfaction with e-government services, web readiness and web presence quality) on use of e-government services was significant $\left(\mathrm{F}(6,842)=66.174 ; \mathrm{R}=.566, \mathrm{R}^{2}=.320\right.$, Adj. $\mathrm{R}^{2}=.316$; $\mathrm{P}<.05)$.

Table 7. Relationship between the dependent variable and independent variables (citizens)

\begin{tabular}{|l|l|l|l|l|l|}
\hline Model & Sum of Squares & DF & Mean Square & F ratio & Sig. \\
\hline Regression & 5540.486 & 6 & 923.414 & 66.174 & $\mathbf{. 0 0 0}$ \\
Residual & 11749.465 & 842 & 13.954 & & \\
Total & 17289.951 & 848 & & & \\
\hline
\end{tabular}

$\mathrm{R}=.566 ; \mathrm{R}^{2}=.320 ; \mathrm{Adj} . \mathrm{R}^{2}=.316$ 
Consequently, readiness to use e-government services, perceived quality of e-government services, and perceived satisfaction with e-government services, web readiness and web presence quality are shown to be good joint predictors of use of e-government services. Thus, the null hypothesis was rejected and the alternative hypothesis accepted.

In terms of the relative predictive effects of the independent variables on the use of e-government services by citizens, the result is presented in Table 8 . The results show that the relative contribution of each of the independent variables in predicting the use of e-government services was as follows (in decreasing order of absolute magnitude): satisfaction with the use of e-government services ( $\beta=$ $.307, \mathrm{P}<.05)$, ICT deployment of government services $(\beta=-.202, \mathrm{P}<.05)$, quality of e-government services $(\beta=.186, \mathrm{P}<.05)$, web presence quality $(\beta=.178, \mathrm{P}<.05)$ e-readiness to use e-government services $(\beta=.164, \mathrm{P}<.05)$, web readiness $(\beta=.127, \mathrm{P}<.05)$. Furthermore, the result showed that the predictive relationships between each of perceived quality of e-government services, satisfaction with services, readiness to use e-government services, web readiness, and web presence quality was positive and significant. In contrast, the relationship between ICT deployment of e-government service and use of e-government service was negative and significant (Table 8). This latter result is surprising but is explained further below in the discussion of findings.

Table 8. Relative effects of the independent variables on the dependent variable (citizens, $H_{01}$ )

\begin{tabular}{|l|l|l|l|l|l|}
\hline \multirow{2}{*}{ Model } & \multicolumn{2}{l|}{$\begin{array}{l}\text { Unstandardized } \\
\text { Coefficient }\end{array}$} & \multicolumn{2}{l}{ Standardized } & \multirow{2}{*}{ Sig. } \\
\cline { 2 - 6 } & $\mathbf{B}$ & Std. Error & Beta $(\boldsymbol{\beta})$ & T & \\
\hline (Constant) & 1.121 & .535 & & 2.096 & .036 \\
\hline ICT deployment of e-government services & -.074 & .015 & -.202 & 4.831 & $\mathbf{. 0 0 0}$ \\
\hline Web readiness of e-government websites & .091 & .028 & .127 & 3.193 & $\mathbf{. 0 0 1}$ \\
\hline Web presence quality of government websites & .033 & .007 & .178 & 4.452 & $\mathbf{. 0 0 0}$ \\
\hline $\begin{array}{l}\text { Perceived satisfaction with e-government } \\
\text { services }\end{array}$ & .109 & .013 & .307 & 8.412 & $\mathbf{. 0 0 0}$ \\
\hline Perceived quality of e-government services & .035 & .007 & .186 & 5.142 & $\mathbf{. 0 0 0}$ \\
\hline E-readiness to use e-government services & .278 & .052 & .164 & 5.385 & $\mathbf{. 0 0 0}$ \\
\hline
\end{tabular}

Dependent variable: use of e-government services

\section{Research Hypothesis Two (Business Organizations' Use of E-Government Services)}

There is no significant predictive joint effect of the independent variables (ICT deployment of government services, customer readiness, perceived quality of e-government services, perceived satisfaction with e-government services, web readiness of e-government websites and web presence quality) on use of e-government services by business organizations.

For business organizations, multiple regression analysis was also carried out to find out if there is no significant joint effect of independent variables on use of e-government services by business organizations, and the results are reported in Tables 9 and 10). Table 9 reveals that the joint effect of independent variables on use of e-government was significant $\left(F(6,276)=20.021 ; R=.551, R^{2}=\right.$ .303 , Adj. $\left.\mathrm{R}^{2}=.288 ; \mathrm{P}<.05\right)$.

In terms of the relative predictive effects of the independent variables on the use of e-government services by business organizations, the result is presented in Table 10. The results show that the relative contribution of each of the independent variables in predicting the use of e-government services were as follows (in decreasing order of absolute magnitude): web presence quality ( $\beta=.317$, 
Table 9. Relationship between the dependent variable and independent variables (business organizations, $\mathrm{H}_{02}$ )

\begin{tabular}{|l|l|l|l|l|l|}
\hline Model & Sum of Squares & DF & Mean Square & F ratio & Sig. \\
\hline Regression & 1581.451 & 6 & 263.575 & 20.021 & $\mathbf{. 0 0 0}$ \\
Residual & 3633.609 & 276 & 13.165 & & \\
Total & 5215.060 & 282 & & & \\
\hline
\end{tabular}

$R=.551 ; R^{2}=.303 ;$ Adj. $R^{2}=.288$

$\mathrm{P}<.05)$, perceived satisfaction with e-government services $(\beta=.307, \mathrm{P}<.05)$, web readiness $(\beta=$ $-.271, \mathrm{P}>.05)$, perceived quality of e-government services $(\beta=.242, \mathrm{P}<.05)$, ICT deployment of government services $(\beta=-.063, \mathrm{P}>.05)$, e-readiness to use e-government services $(\beta=.047, \mathrm{P}>$ $05)$. The result showed that for business organizations, perceived satisfaction with e-government services, perceived quality of e-government services and web presence quality predicted the use of e-government services significantly, while each of ICT deployment of government services, e-readiness of business organizations and web readiness did not.

\section{DISCUSSION OF RESULTS}

\section{Research Hypothesis One (Citizens' Use of E-Government Services)}

According to the findings, five out of the six independent variables, that is e-readiness to use e-government services, perceived quality of e-government services, perceived satisfaction with e-government services, web readiness and web presence quality of government websites, jointly significantly predicted the use of e-government services by citizens. This suggests that improvements in these five variables: would improve the use of e-government services by citizens.

However, ICT deployment of government services had a negative and significant predictive relationship with the use of e-government services by citizens. This finding was surprising and led to further examination of the scatter plots of the independent variables with one another and with the use of e-government services by citizens. Figure 1 shows a negative linear relationship between ICT deployment of government services and web presence quality of government websites. In turn, Figure 2 shows a positive relationship between web presence quality of government websites and use of e-government services by citizens. It is proposed here that these separate relationships might explain the surprising negative predictive relationship between ICT deployment of government

Table 10. Relative effects of the independent variables on the dependent variable (business organizations, $\mathrm{H}_{02}$ )

\begin{tabular}{|c|c|c|c|c|c|}
\hline \multirow{2}{*}{$\begin{array}{l}\text { Model } \\
\text { Independent Variables }\end{array}$} & \multicolumn{2}{|c|}{$\begin{array}{l}\text { Unstandardized } \\
\text { Coefficients }\end{array}$} & \multirow{2}{*}{\begin{tabular}{|l|} 
Standardized \\
Beta $(\boldsymbol{\beta})$ \\
\end{tabular}} & \multirow{2}{*}{$\mathbf{T}$} & \multirow{2}{*}{ Sig. } \\
\hline & B & Std. Error & & & \\
\hline (Constant) & 3.688 & .608 & & 6.066 & .000 \\
\hline ICT deployment of e-government services & -.016 & .051 & -.063 & -.312 & .756 \\
\hline Web readiness of e-government websites & -.141 & .094 & -.271 & -1.496 & .136 \\
\hline Web presence quality of government websites & .035 & .013 & .317 & 2.705 & .007 \\
\hline Perceived satisfaction with e-government services & .109 & .013 & .307 & 8.412 & .000 \\
\hline Perceived quality of e-government services & .042 & .012 & .242 & 3.494 & .001 \\
\hline E-readiness to use e-government services & .010 & .011 & .047 & .891 & .374 \\
\hline
\end{tabular}

Dependent variable: use of e-government services 
services and use of e-government services by citizens. A plausible explanation is as follows. ICT deployment by government agencies cannot by itself promote the use of e-government services unless it reflects in web presence quality of government websites. This is because web presence quality latter measures the quality of citizens' experiences when they try to use e-government services through the websites. Thus, if ICT deployment levels by government agencies do not connect well with web presence quality of their websites, then citizens' ease of access to and/or satisfaction with uses of the available services might be poor, leading to discontinued or sporadic use of the websites and the services deployed through them. According to Al-Ghaith, Sanzogni and Sandhu (2010), the quality of the website and its relative advantage had a significant effect on the use of e-services. Also, Kalamatianou (2017) found that user satisfaction had a significant relationship with the use of services, indicating that a positive view about the services will encourage citizens to continue to use the government services in the future.

As earlier stated that ICT deployment had a negative relationship with web presence quality but web presence quality had a positive relationship with the use of e-government services. This suggests that many agencies may be deploying technology (websites, computers, laptops, phones and so on), employing various ICT personnel, this does not translate into improved e-government services as measured by web presence quality of their websites. Thus, if the web presence quality of the websites is low, users quickly get frustrated. Although business organizations bear such frustrations to transact business with the agencies, citizens might discontinue using optional services or hire intermediaries or touts to bear the frustrations on their behalf, at a cost. The situation is not helped by the finding above that ICT deployment by government agencies do not reflect in improved web presence quality of their websites, as the negative relationship in Figure 1 suggests. It also means that ICT deployment by the agencies would remain unconnected and insensitive to the positive relationship between web presence quality and use of e-government services in Figure 2. Such disconnection represents lack of sync between ICT investments in the agencies and progress in providing effective e-government services. This is supported by the study of Dibie and Quadri (2018), which states that there is a negative correlation between e-governance initiatives and federal government efficient service delivery in Nigeria.

The federal government of Nigeria engages mainly in ICT policymaking and regulation through its various agencies, such as the National Communication Commission (NCC), National Broadcasting Commission (NBC), Ministry of Communication Technology and the Ministry of Information. As at the time of this study, Nigerian governments at the federal, state and local levels had not been actively promoting citizens' access to and uptake of their e-services through such strategies as citizen education and mobilization for e-government, adverts of e-services in print, electronic and social mass media, and so on. Thus, citizens are mostly left to their initiatives and devices to explore, become aware of, gain access to, and use by themselves the relatively unknown e-government services in the country. Thus potential customers of the e-services are left. According to Ingrams, Manoharan, Schmidthuber and Holzer (2018), citizen engagement and readiness are among the critical areas to address in e-government research because government efforts in this area are frequently hampered. Also, according to Keramati, Behmanesh and Noori (2018), readiness factors play a determining role in benefiting from e-government projects, consequently, e-government projects might fail if the readiness is low.

\section{Research Hypothesis Two (Business Organizations' Use of E-Services)}

For business organizations, ICT deployment of e-government services, web readiness of e-government websites, and e-readiness to use e-government services did not predict the use of e-government services. Nevertheless, the other three independent variables, namely web presence quality of government websites, perceived satisfaction with use of e-government services, and perceived quality of e-government services had significant predictive relationships with the use of e-government services by business organizations. These results suggest that improvements in any of these three 


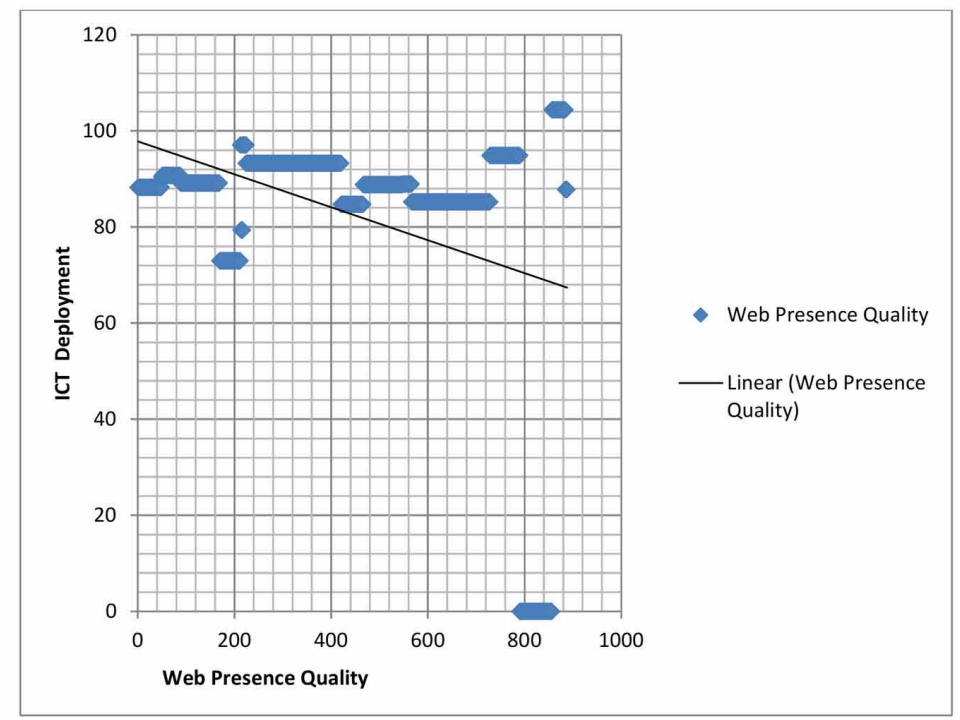

independent variables (web presence quality of government websites, perceived satisfaction with use of e-government services, and perceived quality of e-government services) would likely lead to an increase in the use of e-government services by business organizations. This is supported by Colesca and Liliana (2008), Mohamed, Hussin and Hussein (2009), Al-Ghaith, Sanzogni and Sandhu (2010), and Kalamatianou (2017).

The above findings for business organizations differ interestingly from those for the citizens. For citizens, all the independent variables individually significantly predicted the use of e-government services, although ICT deployment predicted negatively. However, for business organizations, ICT deployment of e-government services, web readiness of e-government websites, and e-readiness to use e-government services did not significantly predict their use of e-government services. The reasons for the differences can be explained as follows. The reason ICT deployment by government agencies was unrelated to the use of e-government services had been explained in the discussion of the findings for hypothesis one above. The lack of relationship between web readiness of e-government services and use of e-government services by business organizations could be because business organizations have multiple access channels to information about government agencies beyond the websites and are therefore less motivated to use the websites to access e-government services, compared to individual citizens. Finally, the lack of relationship between the e-readiness of business organizations and their use of e-government services might be because their e-readiness statuses are determined more by their operational requirements than by the occasional need to do business with government agencies through the websites. Also, business organizations are less motivated or demotivated by the enablers and inhibitors in using government websites to do business with government agencies than individual citizens. Based on the research findings from this study, a research model developed and validated by the researchers is hereby presented in Figure 3:

The study contributed the following to knowledge on e-government: 


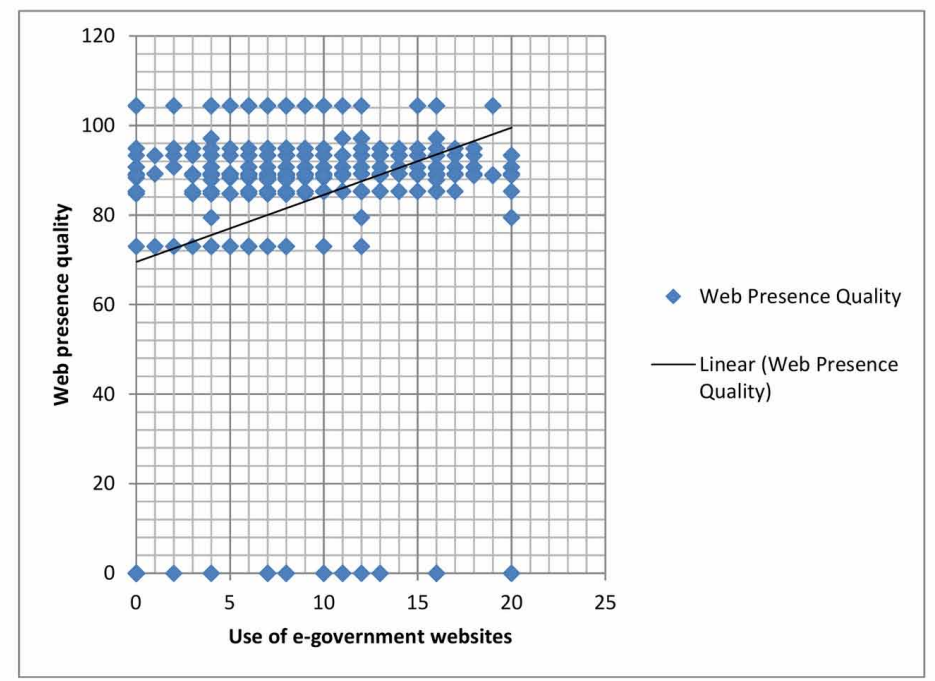

(i) it identified key supply-side and demand-side variables, as well as interrelated and validated them. The supply-side variables were ICT deployment, web readiness and web presence quality, while the demand-side variables were customer readiness, perceived quality of e-government services, and perceived satisfaction with e-government services.

(ii) it demonstrated how the interrelationships among the supply-side variables, demand-side variables and use of e-government services provide a model for understanding adoption and use of e-government services.

\section{CONCLUSION AND RECOMMENDATIONS}

The main conclusion of this study is that the use of e-government services by citizens depended largely more on behavioural (demand-side) than technological (supply-side) factors. This is supported by the finding that out of the six independent variables in the validated research model of the study, perceived satisfaction with e-government services had the highest predictive relationship with the use of e-government services, particularly among citizens. The government agencies should deploy e-government services and channels that improve the satisfaction to customers rather than providing only sophisticated services.

\section{Implications of the Research for Public Policies}

There is a need for policies in Nigeria that call for periodic user satisfaction assessment surveys of e-government customers, as well as Speed Test System (STS) and Broadband Measurement Service (BMS). The purpose of the STS and BMS is to collect accurate data from users directly by the government and not rely on reports from the ICT service providers. This will help the Nigerian government to generate relevant data that can help in gauging adequacy, access to and ease-of-use of the infrastructure by citizens and organisations. STS and BMS will give information about the technical details of the service(s) provided, whereas, user satisfaction assessment will give information 
on the perception of government customers, therefore adopting these approaches will enable the government to get a balanced perspective about the e-government services provided in the country.

There is a need to also implement website improvement policies and enhancements that meet the special needs of people living with disabilities. This is because most Nigerian government websites do not take into account the special needs of people living with disabilities to support their use of e-government services.

\section{Future Research Directions}

Investigation of the effect of socio-economic variables, such as age, income, educational status, access and the cost of the Internet as predictors of use of e-government services in Nigeria.

Finally, citizens should be enlightened about e-government services through proactive and aggressive promotional campaigns, and also involved other stakeholder groups in developing e-government service strategies in the country. Creating a community-based and oriented ICT practice in the country will help the adoption and use of e-government services in Nigeria.

\section{ACKNOWLEDGMENT}

This work was supported by the Faculty of Information and Media Studies (FIMS), University of Western Ontario, London, Ontario, Canada with funds from Canadian Bureau for International Education (CBIE) on behalf of Department of Foreign Affairs and International Trade (DFAIT), Canada [2009]; the John D. and Catherine T. MacArthur Foundation, USA [2010]; the Social Science Research Council (SSRC), USA with funds from Carnegie Corporation, USA [2012]. 
Figure 3. Validated research model

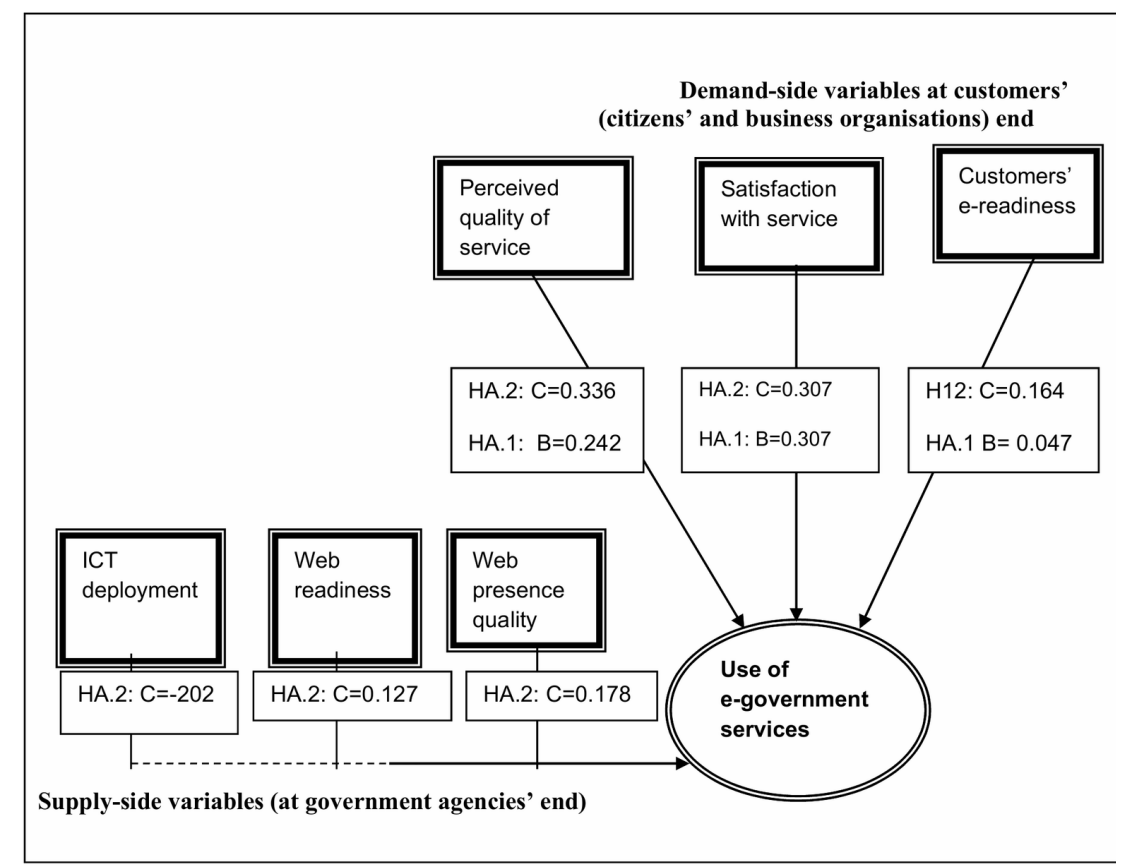




\section{REFERENCES}

Accenture (2005). Leadership in Customer Service: New Expectations, New Experiences. The Government Executive Series. Retrieved on October 5, 2010, from http://www.accenture.com/NR/rdonlyres/F45CE4C89330-4450-BB4A AF4E265C88D4/0/leadership_cust.pdf

Adebiyi, A. A., Ayo, C. K., \& Adebiyi, M. O. (2010). Development of electronic government procurement (eGP) system for Nigeria public sector. International Journal of Electrical \& Computer Sciences, 10(6), 69-76.

Akunyili, D. (2010). ICT and e-government in Nigeria: opportunities and challenges. World Congress on Information Technology. Retrieved April 13, 2011, from www.goafrit.wordpress.com/2010/06/12/ict-and-egovernment-in-Nigeria

Al-Ghaith, W., Sanzogni, L., \& Sandhu, K. (2010). Factors influencing the adoption and usage of online services in Saudi Arabia. The Electronic Journal on Information Systems in Developing Countries, 40(1), 1-32. Retrieved September 3, 2013, from http://www.ejisdc.org

Alomari, M. K., Woods, P., \& Sandhu, K. (2009). The Deployment of e-government in the Hashemite Kingdom of Jordan: factors in e-government adoption. IADIS International ConferenceWWW/INTERNET. 19-22 November 2009.

Amagoh, F. (2016). Determinants of E-Government Diffusion in Nigeria: An Examination of Theoretical Models. Information Development, 32(4), 1137-1154.

Colesca, S. E., \& Liliana, D. (2008). E-government adoption in Romania. World Academy of Science, Engineering and Technology, 42, 140-145.

Curtin, G. G., Sommer, M. H., \& Vis-Sommer, V. (Eds.). (2003). The world of e-government. New York: The Haworth Press, Inc.

DePaulaa, N., Dincellia, E., \& Harrison, T. M. (2018). Toward a Typology of Government Social Media Communication: Democratic Goals, Symbolic Acts and Self-Presentation. Government Information Quarterly, $35,98-108$.

Dibie, R. A., Maryam, O., \& Quadri, M. O. (2018). Analysis of the Effectiveness of E-Government in the Federal Government of Nigeria. Journal of Public Administration and Governance, 8(3), 75-98.

Eom, S., Hwang, H., \& Kim, J. H. (2018). Can Social Media Increase Government Responsiveness? A Case Study of Seoul, Korea. Government Information Quarterly, 35, 109-122.

Faaeq, M. K., Mat, N. K. N., Faieq, A. K., Rasheed, M. M., \& Al-Salami, Q. H. (2018). Towards of Smart Cities Based on the Sustainability of Digital Services. International Journal of Engineering and Technology, 7(4.28), 436-442.

Faris, R., \& Heacock, R. (2013). Measuring Internet activity: a (selective) review of methods and metrics. Internet Monitor Special Report Series No. 2. The Berkman Center for Internet \& Society Research Publication Series, Harvard University. Retrieved November 15, 2013, from http://ssrn.com/abstract=2353457

Gay, L. R., \& Airasian, P. (2000). Educational research: competence for analysis (6th ed.). Merrill.

Ingrams, A., Manoharan, A., Schmidthuber, L., \& Holzer, M. (2018). Stages and Determinants of E-Government Development: A Twelve-Year Longitudinal Study of Global Cities. International Public Management Journal. Advance online publication. doi:10.1080/10967494.2018.1467987

Kalamatianou, M. A. (2017). A Suggested Framework for the Evaluation of e-Government Services. A Suggested Framework for the Evaluation of E-government Services. International Journal on Advances in Internet Technology, 10(3 \& 4), 124-133.

Kaylor, C., Deshazo, R., \& Van Eck, D. (2001). Gauging e-government: A report on implementing services among American cities. Government Information Quarterly, 18(2), 293-307.

Keramati, A., Behmanesh, I., \& Noori, H. (2018). Assessing the impact of readiness factors on e-government outcomes: An empirical investigation. Information Development, 34(3), 222-241. 
Kling, R. (2000). Learning about information technologies and social change: The contribution of social informatics. The Information Society, 16(3), 217-232.

Mohamed, N., Hussin, H., \& Hussein, R. (2009). Measuring Users' Satisfaction with Malaysia's Electronic Government Systems. Electronic. Journal of E-Government, 7(3), 283-294.

Ogunsola, K. (2015). Predictors of use of electronic government services in Nigeria (Unpublished doctoral thesis). University of Ibadan, Ibadan, Nigeria.

Ogunsola, K. \& Ojebola, T. (2017). Users' Assessment of the Quality of Information Disseminated through Facebook by Selected Law Enforcement Agencies in Nigeria. Electronic Government, an International Journal, 13(2), 129-147.

Ogunsola, K., \& Olojo, T. P. (2020). Towards Connected Governance: Case Studies of Factors Influencing Citizens' Continuance Usage Intention of Web 2.0. In Nigeria. Web 2.0 and Cloud Technologies for Implementing Connected Government (pp. 68-94). IGI Global.

Ogunsola, K., \& Tiamiyu, M. A. (2017). Assessment of Levels and Interrelationships of ICT Deployment, Web Readiness, and Web Presence Quality of Nigerian E-Government Websites. In Handbook of Research on Sustainable ICT Adoption and Integration for Socio-Economic Development. IGI Global.

Olatokun, W. M. (2006). National Information Technology Policy in Nigeria: Prospects, Challenges and Framework for Implementation. African Journal of Library Archives and Information Science, 16(1), 9-18.

Oni, A., Okunoye, A., \& Mbarika, V. (2016). Evaluation of E-Government Implementation: The Case of State Government Websites in Nigeria. Electronic. Journal of E-Government, 14(1), 48-59.

Quirchmayr, G., Funilkul, S., \& Chutimaskul, W. (2007). A Quality Model of E-Government Services based on the ISO/IEC 9126 Standard. Retrieved December 10, 2015, from https://sit.kmutt.ac.th/wichian/Paper/ eGovServiceQualityModel.pdf

Rabaa'i, A. A. (2015). An Empirical Investigation on the Adoption of E-government in Developing Countries: The Case of Jordan. Computer and Information Science, 8(3), 83-102.

Ronchi, A. M. (2019). E-government: Background, Today's Implementation and Future Trends. In e-Democracy. Springer.

Siew, L. S., \& Leng, L. Y. (2003). E-government in action: Singapore case study. In The World of E-government. The Haworth Press, Inc.

Tiamiyu, M. A. (2005). Using Information Technology for Total Quality Management of Government Business in Nigeria. ITCC Training Course Akure, Nigeria, 1-17.

Tiamiyu, M. A., \& Ogunsola, K. (2008). Preparing for e-government: Some findings and lessons from government agencies in Oyo State, Nigeria. South African Journal of Library and Information Science, 74(1), 58-72.

United Nations. (2008). From e-government to connected governance. Retrieved February 10, 2009, from http:// unpan1.un.org/intradoc/groups/public/documents/UN/UNPAN028607.pdf

United Nations. (2010). World e-government rankings. Retrieved October 21, 2011, from http://kz.mofcom.gov. cn/accessory/201009/1284225105383.pdf

Wong, W., \& Welch, E. (2004). Does e-government promote accountability? A comparative analysis of website openness and government accountability. governance. International Journal of Policy, Administration, and Institutions, 17(2), 275-297. 


\section{APPENDIX A. E-GOVERNMENT SERVICE POINTS WHERE QUESTIONNAIRE DATA WERE COLLECTED}

1. Federal Road Safety Corps (FRSC, Lagos)

2. Lagos Internal Revenue Service (LIRS, Alausa)

3. Lagos State University (LASU)

4. Lagos University Teaching Hospital (Pharmaceutical section)

5. National Orthopedic Hospital, Igbobi, Lagos (Pharmaceutical section)

6. Nigeria Customs Service (Murtala Muhammed International Airport, Ikeja)

7. Nigeria Immigration Service (FESTAC Town, Lagos)

8. Nigeria Port Authority, Apapa Warf, Lagos

9. Nigerian Aviation Handling Company Plc. (NAHCO), (Murtala Muhammed International Airport, Ikeja) Lagos

10. University of Lagos, Lagos

11. Federal In-land Revenue Service (FIRS, Port-Harcourt)

12. Federal Road Safety Corps (FRSC, Port-Harcourt)

13. National Agency for Food, Drug Administration and Control (NAFDAC, Port-Harcourt)

14. National Open University of Nigeria (NOUN, Port-Harcourt)

15. Nigeria Customs Service, Federal Secretariat (Port Harcourt)

16. Nigeria Immigration Service, Federal Secretariat (Port Harcourt)

17. Port Harcourt International (Omagwa International) Airport

18. Rivers State University of Education

19. Abuja Geographic Information service

20. Federal In-land Revenue Service (FIRS, Abuja)

21. National Hospital, Garki, Abuja

22. National Open University of Nigeria (Abuja)

23. Nigeria Customs Service (Nnamdi Azikiwe International Airport)

24. University of Abuja, Abuja 


\section{APPENDIX B. LIST OF GOVERNMENT WEBSITES VISITED}

\begin{tabular}{|c|c|c|c|c|c|}
\hline \multicolumn{6}{|c|}{ State government websites accessed } \\
\hline 1. & Abia & www.abiastate.gov.ng & 17. & Imo & www.imostate.gov.ng \\
\hline 2. & Adamawa & www.adamawastate.gov.ng & 18. & Jigawa & www.jigawastate.gov.ng \\
\hline 3. & $\begin{array}{l}\text { Akwa- } \\
\text { Ibom }\end{array}$ & www.aksgonline.com & 19. & Kaduna & www.kadunastate.gov.ng \\
\hline 4. & Anambra & www.anambrastate.gov.ng & 20. & Kano & www.kano.gov.ng \\
\hline 5. & Bauchi & www.bauchistate.gov.ng & 21. & Kastina & www.kastinastate.gov.org \\
\hline 6. & Bayelsa & www.bayelsa.gov.ng & 22. & Kwara & www.kwarastate.gov.ng \\
\hline 7. & Benue & www.benuestate.gov.ng & 23. & Lagos & www.lagosstate.gov.ng \\
\hline 8. & Borno & www.bornostate.gov.ng & 24. & Nasarawa & www.nasarawastate.gov.ng \\
\hline 9. & $\begin{array}{l}\text { Cross } \\
\text { River }\end{array}$ & www.crossriverstate.gov.ng & 25 . & Niger & www.nigerstate.gov.ng \\
\hline 10. & Delta & www.deltastate.gov.ng & 26. & Ogun & www.ogunstate.gov.ng \\
\hline 11. & Eboyin & www.ebonyionline.com & 27. & Ondo & www.ondostate.gov.ng \\
\hline 12. & Edo & www.edostate.gov.ng & 28. & Oyo & www.oyostate.gov.ng \\
\hline 13. & Ekiti & www.ekitistate.gov.ng & 29. & Plateau & www.plateaustate.gov.ng \\
\hline 14. & Enugu & www.enugustate.gov.ng & 30. & Rivers & www.riversstate.gov.ng \\
\hline 15. & $\begin{array}{l}\text { Federal } \\
\text { Capital } \\
\text { Territory } \\
\text { (FCT) }\end{array}$ & www.fct.gov.ng & 31. & Sokoto & www.sokotostate.gov.ng \\
\hline 16. & Gombe & www.gombestate.gov.ng & 32. & Yobe & www.yobestate.gov.ng \\
\hline \multicolumn{6}{|c|}{ Websites of Local government / local council development areas accessed } \\
\hline 1. & \multicolumn{4}{|c|}{ Ajeromi Ifelodun Local Government, Lagos } & www.ajeromi-ifelodun.com \\
\hline 2. & \multicolumn{4}{|c|}{ Amuwo Odofin Local Government, Lagos } & www.amuwo-odofin.gov.ng \\
\hline 3. & \multicolumn{4}{|c|}{ Badagry Local Government, Lagos } & www.badagrygov.org \\
\hline 4. & \multicolumn{4}{|c|}{$\begin{array}{l}\text { Mosan Okunola Local Council Development Authority, } \\
\text { Lagos }\end{array}$} & www.mosanokunola.com \\
\hline 5. & \multicolumn{4}{|c|}{ Odo-Otin Local Government, Lagos } & www.odo-otin.os.gov.ng \\
\hline 6. & \multicolumn{4}{|c|}{ Ojo Local Government, Lagos } & www.ojolga.org \\
\hline 7. & \multicolumn{4}{|c|}{ Onigbongbo Local Government, Lagos } & www.onigbongbogov.org \\
\hline 8. & \multicolumn{4}{|c|}{ Oshodi Isolo Local Government, Lagos } & www.oshodiisolo.lg.gov.ng \\
\hline 9. & \multicolumn{4}{|c|}{ Yaba Local Council Development Authority, Lagos } & www.yabagov.org \\
\hline
\end{tabular}


Kemi Ogunsola (PhD) obtained Master and Ph.D. degrees in Information Science, from Africa Regional Centre for Information Science, University of Ibadan, Nigeria. She is a Senior Lecturer whose research focuses on applying information and communication technologies (ICT) to development. She became a Next Generation Social Science Research in Africa fellow in 2011; an award by the Social Science Research Council (SSRC), New York, USA. She is a fellow of Carnegie Corporation of U.S.A. She has published articles in both local and international journals. She has also made presentations at international conferences.

Mutawakilu Adisa Tiamiyu is Professor of Information Science at the Africa Regional Centre for Information Science, University of Ibadan, Nigeria, where he has been teaching, researching and consulting since 1990. He holds a master's degree in economics from the University of Ibadan, doctorate degree in information science from the University of Western Ontario, Canada, had worked in government agencies in Nigeria for over ten years, and researched for them for over two decades. His research interests include e-government, evidence use in policy making, management information systems, decision support systems, and knowledge organization. He has authored and edited five books and published over sixty articles in internationally reputed journals. 